
ТЕОРЕТИЧНІ ЗАСАДИ ФОРМУВАННЯ УПРАВЛІНСЬКОЇ КОМПЕТЕНТНОСТІ
МАЙБУТНІХ МЕНЕДЖЕРІВ СПОРТИВНОЇ ДІЯЛЬНОСТІ

\title{
THEORETICAL PRINCIPLES OF FORMING THE ADMINISTRATIVE COMPETENCE OF FUTURE MANAGERS OF SPORTS ACTIVITIES
}

\author{
Стаття присвячена висвітленню теоре- \\ тичних засад орормування управлінської ком- \\ петентності майбутніх менеджерів спор- \\ тивної діяльності. Зазначено, що науковці \\ розглядали різні аспекти просресійної компе- \\ тентності та культури менеджера у спор- \\ тивній діяльності, проблему орормування \\ управлінської компетентності. Достатньо \\ уваги приділялося дослідженню проблем орга- \\ нізації та технології менеджменту суб'єктів \\ та об'єктів управління фрізичною культурою \\ та спортом, а також загальних проблем \\ менеджменту освіти. Проведений аналіз \\ наукових праць, присвячених фрормуванню \\ профресійної та управлінської компетент - \\ ності майбутніх менеджерів спортивної \\ діяльності, свідчить про те, що ця проблема \\ як у теоретичному, так і в методологічному \\ аспектах досліджена недостатньо. Автор \\ наголошує, що розвиток фрізкультурно-спор- \\ тивного руху в ринкових умовах неможливий \\ без фрахово підготовлених, компетентних \\ менеджерів. Встановлено, що формуванню \\ управлінської компетентності майбутніх \\ менеджерів спортивної діяльності сприя- \\ тиме комплексний компетентністний підхід, \\ який дасть змогу підготувати квалісрікова- \\ них менеджерів спортивної діяльності. Нада- \\ ється визначення поняттям «компетент- \\ ність», «компетенція» та «менеджмент». \\ Порівнюються такі поняття, як компетент- \\ ність та компетениія, з'ясовується різниця \\ між цими двома поняттями. У статті ілю- \\ струється історія виникнення та розвитку \\ менеджменту як взагалі, такі в Україні. Автор \\ підкреслює важливість фрормування управлін- \\ ської компетентності під час фрахової під- \\ готовки майбутніх менеджерів спортивної \\ діяльності. У статті також ідеться про те, \\ що доцільним буде виховувати у майбутніх \\ фахівців особистісні якості, які також спри- \\ яють формуванню професійної компетент- \\ ності майбутніх фрахівців. На думку автора, \\ формування управлінської компетентності \\ майбутнього менеджера спортивної діяль- \\ ності у процесі фрахової підготовки має \\ базуватися на загальнолюдських цінностях, \\ комплексному компетентністному підході \\ ma профресійній компетенції майбутнього \\ фахівця, необхідних під час роботи у складних \\ сочіально-економічних умовах.
}

Ключові слова: компетентність, компетенція, професійна компетентність, менеджмент, управлінська компетентність.

The article is devoted to the presentation of theoretical principles of forming the administrative competence of future managers of sports activities. It was noted that the researchers considered various aspects of professional competence and culture of the manager in sporting activities, the problem of forming managerial competence. Enough attention was paid to the study of the organization and technology of management of subjects and objects of physical culture and sports management, as well as general problems of education management. The analysis of scientific works devoted to the formation of professional and managerial competence of future managers of sports activities shows that this problem is not sufficiently investigated both theoretically and methodologically. The author stresses that the development of physical culture and sports movement in market conditions is impossible without skilled and competent managers. It is established that the formation of administrative competence of future managers of sports activities will be facilitated by a comprehensive competence approach, which in turn will provide the opportunity to prepare skilled managers of sports activities. The definition of competence, competency and management is given. Such concepts as competence and competency are compared; the difference between these two concepts is clarified. The article illustrates the history of the emergence and development of management in general, and in Ukraine. The author emphasizes the importance of forming administrative competence during the professional training of future managers of sports activities. The article also mentions that it would be rational to educate future personalities on personal qualities which also contribute to the formation of professional competence of future specialists. According to the author, the formation of managerial competence of the future manager of sporting activities in the process of professional training should be based on universal values, a comprehensive competence approach and professional competence of the future specialist that are necessary during work in complex socio-economic conditions.

Key words: competence, competency, professional competence, management, administrative competence.
Постановка проблеми у загальному вигляді. В умовах глобалізації, технологічного вибуху та стрімкого економічного прогресу на перший план виходять базові та соціальні компетенції. $€$ підстави вважати, що лише компетентністний підхід до професійної підготовки майбутніх фрахівців дає можливість успішно поєднувати як власні інтереси, так і інтереси суспільства. Наша сьогоденність, активна євроінтеграція всіх сорер суспільного життя вимагають змін у профресійній діяльності кожного члена суспільства.

Перехід на ринкову економіку, інтеграція у міжнародний освітній простір, демократизація та гуманізація суспільного життя у країні набули найбільшої актуальності. Соціально-економічні перетворення зумовили нові завдання, пов'язані 3 удосконаленням системи вищої освіти, фрізичного виховання та спорту, що постали перед державою. Вирішення цих завдань відбуватиметься за умов фрормування ціннісних орієнтацій населення, спрямованих на зміцнення здоров'я, організацію здорового способу життя, підвищення рівня орізичного виховання молоді, які сьогодні визивають глибоку занепокоєність і стають викликом для суспільства на сучасному етапі його розвитку $[6$, с. 11$]$. 
Звичайно, динамічний розвиток суспільства висуває й нові вимоги до системи вищої професійної освіти в Україні. Насамперед зміни, що відбуваються в економіці, потребують використання нових методів і підходів в освітній галузі підготовки фрахівців. Сучасний етап розвитку сорери фрізичної культури і спорту зумовлює нові вимоги до кадрового забезпечення цієї сфери гуманітарної політики. На думку багатьох науковців, розвиток управлінської компетентності менеджера спортивної діяльності $€$ складним, багатостороннім процесом. щоб стати справжнім управлінцем у сфері фрізичної культури і спорту, керівнику спортивного закладу під час управління необхідно знати і володіти усіма аспектами психолого-педагогічних наук, соціологічних, культурологічних, бути фрахівцем у сорері фрізичної культури і спорту, освітнього менеджменту, а також бути компетентним у різних галузях науки й людинознавства.

Аналіз останніх досліджень і публікацій. Питання профресійної компетентності майбутніх менеджерів фрізичного виховання і спорту були предметом дослідження науковців протягом багатьох десятиліть. Серед сучасних дослідників зазначену проблему вивчали М. Дудчак, О. Жданова, В. Жолдак, Ю. Мічуда, І. Переверзін, В. Саюк та ін. Автори розглядали різні аспекти професійної компетентності та культури менеджера у спортивній діяльності. Проблема фрормування саме управлінської компетентності висвітлюється в роботах $€$ Є. Воробйова, Т. Глушмана, О. Гонтарук, Ю. Дубревського, В. Жигирь, С. Колодезникової, С. Криштанович, І. Сарафранової, О. Свєртнєва, та ін.

У попередні роки достатньо уваги приділялося дослідженню проблем організації та технології менеджменту суб'єктів і об'єктів управління фрізичною культурою та спортом у роботах О. Горбенко, Н. Петренко, І. Приходько, Г. Путятіної, І. Хомко; вивченням загальних проблем менеджменту освіти займалися А. Бойко, І. Корольова, А. Черниш; проблеми кадрового забезпечення сорери фрізичної культури і спорту вивчають О. Жданова, Т. Курчаба та ін.

Було здійснено обґрунтування гуманоцентричної та соціоцентричної переорієнтації освіти в умовах ринкових відносин для того, щоб задовольнити потреби як особистості, так і суспільства. Це питання висвітлювали у своїх роботах такі науковці, як: В. Андрущенко, О. Долженко, С. Клепко, Х. Тхагансоєв, Г. Щедровицький та ін. Розв'язанню проблем управління освітою, освітнього менеджменту присвячені праці М. Гончарова, М. Гриньової, В. Крижко, А. Моїсеєва, В. Симонова, Н. Ушакової та ін.

Виділення невирішених раніше частин загальної проблеми. Формуванню управлінської компетенції не було приділено достатньо уваги, але необхідність ефективної системи підготовки менеджерів зумовлена також рефрормуванням галузі фрізичної культури і спорту. Сучасні погляди на ефрективність профресійної діяльності керівників підприємств, державних установ, громадських і спортивних організацій, закладів вищої освіти звертаються до найбільш глибокого вивчення питань, які перебувають у площині виробничих відносин, підвищення ефективності праці та її продуктивності, мотивації та стимулювання працівників, урегулюванням людських взаємовідносин [5, с. 91].

Аналіз великої кількості досліджень із цього питання свідчить, що цілісної концепції у зазначеному напрямі ще не розроблено, немає також наукових праць, які б комплексно висвітлювали питання фрормування управлінської компетентності майбутнього менеджера спортивної діяльності. Саме зазначені питання послужили основою для нашої роботи.

Мета статті - висвітлити науково-теоретичні засади фрормування управлінської компетентності майбутніх менеджерів спортивної діяльності.

Виклад основного матеріалу. Розвиток фрізкультурно-спортивного руху в ринкових умовах неможливий без фахово підготовлених, компетентних менеджерів, які здійснюватимуть на професійній основі свою діяльність, забезпечуватимуть активізацію інноваційної активності, фрормування ефрективної інвестиційної політики та соціальної інорраструктури у країні, розвиток видів спорту та фрізкультурно-спортивних послуг тощо.

За Міжнародною стандартною класифрікацією профресій 2008 р. (International Standard Classification of Occupations 2008 - ISCO-2008) «Менеджери (керівники)» (Managers) планують, спрямовують, координують та оцінюють всебічну діяльність підприємств, урядових структур та інших організацій, які $є$ у їхньому складі, а також фрормулюють і аналізують їх політику, нормативні акти, правила та настанови [4, с. 594].

Аналіз наукової літератури показує, що еволюція терміна «менеджмент» (від англійського management - управління) привела до відмінностей у тлумаченні цього поняття. Фундаментальний Оксорордський словник англійської мови наводить чотири значення слова «менеджмент»: 1) спосіб (манера) спілкування з людьми; 2) мистецтво управління; 3) специфічні здібності й адміністративні навички; 4) орган управління, адміністративна одиниця. В інших джерелах «менеджмент» визначають як наукову дисципліну, що висвітлює проблеми управління, вивчає техніко-організаційні та соціальні аспекти управління суспільним виробництвом [1].

Таким чином, менеджмент - це управління будь-яким соціальним об'єктом; володіння майстерністю управління; профресіоналізм організатора виробництва, що забезпечує високий рівень 
ефрективності праці без жорсткого адміністрування. В англомовних країнах цим словом виражають фрункцію, навчальну дисципліну, професію, галузь наукового дослідження.

Підготовку спеціалістів за напрямом підготовки «Менеджмент» в Україні розпочато в 1994 р. Фахівці 3 менеджменту користуються сьогодні підвищеним попитом на ринку освітніх послуг. Фахівець за напрямом підготовки «Менеджмент» за умов набуття відповідного досвіду може адаптуватися до таких видів суміжної професійної діяльності: економічної, маркетингової, обліковоконтрольної, зовнішньоекономічної, освітньої, науково-дослідницької.

Дослідження вчених свідчать про те, що у різних країнах світу система підготовки спортивних менеджерів у закладах вищої освіти почала складатися 3 другої половини 80-х рр. XX ст. Відтоді і донині накопичено значний теоретичний і практичний досвід діяльності спортивного менеджера, що розглядається у літературі різними авторами. Із часів незалежності України сорера управління фрізичною культурою і спортом отримує фрахівців широкого профрілю, які можуть посідати різноманітні управлінські посади, але працівники фрізкультурно-спортивних організацій дедалі більше переконуються в необхідності використання основних надбань сучасного менеджменту. Тому соціальна практика поставила сьогодні на перший план створення в Україні цілісної структурної системи менеджменту, що передбачає оволодіння майбутніми фрахівцями необхідними професійними компетентностями з метою поліпшення ефективності фрізкультурно-оздоровчої та спортивної роботи в сучасних умовах ринкової економіки [9, с. 19-20].

Компетенція -добра обізнаність із чим-небудь; коло повноважень якої-небудь організації, установи або особи; сукупність прав і обов'язків, якими у певній галузі наділені підприємства. установи, організації або службові особи. Компетентність обізнаність, кваліфікованість, поінорормованість або авторитетність у якій-небудь галузі.

Було з'ясовано, що в галузі фрізичної культури й освіти поняття «компетентність» трактується як універсальна передумова професійного становлення особистості у реальній соціально-економічній ситуації відповідно до умов, що складаються у суспільстві; сорера діяльності, у якій реалізується просресійна компетентність.

У педагогічній науці терміни «компетенція» і «компетентність» визначають нові реалії і завдання у зв'язку з підготовкою молоді до активної участі у громадському житті. Компетентність - це якість особистості, що передбачає володіння визначеною компетенцією. У свою чергу, профресійна компетентність розглядається як індивідуальна характеристика ступеня відповідності вимогам профресії; індивідуально-психологічне утворення, яке включає досвід, знання, уміння, профресійноважливі якості, психологічну готовність [6, с. 12].

У наукових дослідженнях останніх років поняття «компетентність» розглядається як вищий рівень професійної діяльності, що вивчається акмеологією (А. Деркач, В. Рибалка). Саме тому вчені акмеологічного напряму дійшли висновку, що для ефективного здійснення професійної управлінської діяльності керівник спортивного закладу повинен володіти не тільки професіоналізмом діяльності, а й професіоналізмом особистості.

Таким чином, професійна управлінська компетентність визначає обсяг компетенцій, коло повноважень у сорері управлінської діяльності, тобто питання, у яких суб'єкт володіє пізнаннями, досвідом, навичками, що відображають соціально-професійний статус та управлінську кваліфікацію, а також певні особистісні, індивідуальні здібності для реалізації професійної діяльності [3, с. 126].

Методологічною основою сучасних досліджень із профресійної освіти є компетентністний підхід, який у «Національному освітньому глосарії: вища освіта» обґрунтовано як «підхід до визначення результатів навчання, що базується на їх описі у термінах компетентностей». Зазначається також: «Компетентнісний підхід є ключовим методологічним інструментом реалізації цілей Болонського процесу» [7, с. 31]. Компетентнісний підхід розкриває цілі, зміст і методологію професійної освіти. Профресійна компетентність майбутніх менеджерів фрізичної культури та спорту розглядається як цілісна характеристика індивіда, об'єднання знань, умінь і навичок, які продукують професійний інтелект, фрахові позиції та індивідуально-психологічні особливості цих фрахівців [7, с. 46].

Профресійна компетентність фрахівця галузі фрізичного виховання і спорту розглядається як інтегрована професійно-особистісна характеристика у програми навчальних закладів, яка повинна забезпечувати ефрективний рівень їх профресійної діяльності та відображати рівень сорормованості профресійної компетентності, що визначаються сукупністю мотиваційних і ціннісних установок, зумовлених необхідним обсягом знань і вмінь, рівнем профресійної майстерності та досвідом роботи в обраній сорері діяльності [2, с. 124].

Висновки. Ефективне управління педагогічним, навчально-тренувальним процесом або структурою фрізкультурно-спортивної спрямованості залежить від компетентності працівника, яка передбачає у нього наявність спеціальної освіти, широкої загальної та спеціальної ерудиції, постійне підвищення науково-профресійної підготовки, що забезпечується діловими й особистісними якостями, які можна розглядати як ключ до ефективного виконання професійних обов'язків [5, с. 92].

Ми вважаємо, що фрормування управлінської компетентностімайбутньогоменеджераспортивної 
діяльності у процесі фрахової підготовки має базуватися на загальнолюдських цінностях, комплексному компетентністному підході та профресійній компетенції майбутнього фрахівця, які $€$ необхідними під час роботи у складних соціально-економічних умовах. Відтак можна впевнено стверджувати, що розвиток у майбутніх менеджерів спортивної діяльності готовності до здійснення самостійної пізнавальної роботи, стимулювання їхнього творчого мислення у специфрічних професійно зумовлених ситуаціях дає можливість надалі есрективно організовувати працю, підвищувати продуктивність, вдало здійснювати управління колективом, персоналом, процесом навчання, виховання молоді, підготовку спортсменів тощо.

Перспективами в цьому напрямі $€$ подальше дослідження вищезазначеної проблеми, а саме розробка поняття «управлінська компетентність», визначення пріоритетних особистісних якостей щодо її фрормування у процесі профресійної фрахової підготовки майбутніх менеджерів спортивної діяльності.

\section{БІБЛІОГРАФІЧНИЙ СПИСОК:}

1. Білобровко Т.І., Борисова Л.В. Кредитномодульний курс з освітнього менеджменту : навчальний посібник. Переяслав-Хмельницький : СКД, 2008. $76 \mathrm{c}$.

2. Войнар Ю., Наварецький Д., Глазирін І. Розвиток та сучасні тенденції системи підготовки фрахівців з фрізичної культури в умовах Євроінтеграції : монограсрія. Черкаси : Відлуння-Плюс, 2005. 184 с.
3. Глінчук Л.М. Теоретичні засади формування управлінської компетентності керівників оздоровчих закладів. Педагогіка фрормування творчої особистості у вищій $і$ загальноосвітній школах : збірник наукових праць. Запоріжжя, 2014. Вип. 34. (87). С. $125-132$.

4. Гонтарук О. Система підготовки менеджерів 3 срізичної культури і спорту в ринкових умовах. Фізична культура, спорт та здоров'я нації : збірник наукових праць. Вінницького державного пед. ун-ту ім. Михайла Коцюбинського. 2016. Вип. 20. С. 593-601.

5. Дубревський Ю.М. Управлінська компетентність як складова профресійної підготовки майбутніх фрахівців фрізичного виховання і спорту. Педагогіка, психологія та медико-біологічні проблеми фрізичного виховання і спорту. Харків, 2008. № 6. С. 91-93.

6. Дубревський Ю.М. Якісний та структурний аналіз управлінської компетентності майбутніх фахівців фрізичного виховання і спорту. Педагогіка, психологія та медико-біологічні проблеми фрізичного виховання і спорту. Харків, 2014. № 6. С. 11-14.

7. Криштанович С. Формування профресійної компетентності майбутніх спортивних менеджерів: наукові підходи. Науковий вісник інституту прооресійно-технічної освіти НАПН України. Профресійна педагогіка. Київ, 2017. № 14. С. 44-49.

8. Національний освітній глосарій: вища освіта / І. Бабин та ін. ; за ред. В. Кременя. Київ : Плеяди, 2011. $100 \mathrm{c}$.

9. Свєртнєв О.А. Характеристика основних компетентностей менеджера фрізичної культури і спорту в сучасних умовах ресрормування вищої освіти. Імідж сучасного педагога. Електронний науковий фраховий журнал. 2017. № 7 (176). С. 19-22. 